\title{
Reinterpreting energy poverty in Zimbabwe: a scalar perspective
}

\author{
Ellen Fungisai Chipango ${ }^{1}$ \\ University of Johannesburg, South Africa
}

\begin{abstract}
Unequal access to electricity has negatively impacted rural households in Zimbabwe. Energy poverty and its impact cannot be understood only at rural household level, but involve the local community, the government, the nature of the state and international relations. The state, non-state and political actors operate across scales and have relational interactions that help to explain inequality in access to energy. Through a qualitative study of Buhera District, Ward 24 and its scalar political ecology, I explain inequalities of access through actor roles and differential power, also finding that patriarchal gender relations play a critical role in socially producing scale in the household. Scalar relations determine policy decisions that are felt by households denied access to electricity.
\end{abstract}

Keywords: scale, energy access, relational processes, energy poverty, socially produced

\section{Résumé}

L'accès inégal à l'électricité a eu un impact négatif sur les ménages ruraux au Zimbabwe. La pauvreté énergétique et son impact ne peuvent pas être compris uniquement au niveau des ménages ruraux, mais impliquent la communauté locale, le gouvernement, le fonctionnement de l'état et les relations internationales. Les acteurs étatiques, non étatiques et politiques opèrent à travers des échelles et ont des interactions relationnelles qui aident à expliquer l'inégalité dans l'accès à l'énergie. Par une étude qualitative du district de Buhera, Ward 24 et son écologie politique scalaire, j'explique les inégalités d'accès par les rôles d'acteur et le pouvoir différentiel, trouvant aussi que les relations patriarcales jouent un rôle critique dans la production sociale d'échelle dans le ménage. Les relations scalaires déterminent les décisions politiques qui sont ressenties par les ménages auxquels l'accès à l'électricité est refusé.

Mots-clés: échelle, accès à l'énergie, processus relationnels, pauvreté énergétique, production sociale

\section{Resumen}

El acceso desigual a la electricidad ha tenido un impacto negativo en los hogares rurales de Zimbabwe. La pobreza energética y su impacto no pueden entenderse solo a nivel de los hogares rurales, sino que involucra a la comunidad local, el gobierno, el funcionamiento del estado y las relaciones internacionales. Los actores estatales, no estatales y políticos operan a través de escalas y tienen interacciones relacionales que ayudan a explicar la desigualdad en el acceso a la energía. A través de un estudio cualitativo del distrito de Buhera, Ward 24 y su ecología política escalar, explico las desigualdades de acceso a través de los roles de los actores y el poder diferencial, y también encuentro que las relaciones de género patriarcales juegan un papel crítico en la producción social de escala en el hogar. Las relaciones escalares determinan las decisiones de política que afectan a los hogares a quienes se les niega el acceso a la electricidad.

Palabras clave: escala, acceso a la energía, procesos relacionales, pobreza energética, producción social

\footnotetext{
${ }^{1}$ Ellen Fungisai Chipango, PhD Candidate, University of Johannesburg, Auckland Park, South Africa. Email: 216068248 "at" student.uj.ac.za. Acknowledgements: The financial assistance of the National Institute for the Humanities and Social Sciences - Council for the Development of Social Science Research in Africa (NIHSS-CODESRIA) is hereby acknowledged. Opinions expressed and conclusions arrived at are those of the author and are not necessarily to be attributed to the NIHSS-CODESRIA. Thankyou to the referees and JPE editors.
} 


\section{Introduction}

The lack of access to energy suffered by Zimbabwe's rural households has its origins in multi-scalar relations of power, and the role of state, non-state and political actors. This article argues that there is a tendency to essentialize and romanticize local problems of energy poverty in isolation from broader economic and political structures. Zimbabwean energy inequalities have been studied: for example, Mehretu and Mutambirwa (1992) assessed the magnitude of time and distance that rural communities experience when accessing basic necessities such as fuelwood and water in the Chiduku Area of Zimbabwe, especially for trips undertaken by women. Informed by Gezon (2005), I depart from this local focus to interrogate the effects of outside political influences on electricity access. This multi-scalar political ecology approach to the analysis of human-environment relationships allows for nuanced views of the role of regional, national and global scales in determining local access to energy (Zimmerer and Bassett 2003).

Following Harvey (1973), most people live in conditions not of their own choosing, with contingent social processes operating across society. The focus of this article is on showing how inequalities of access to electricity are caused by human practices embedded in social structures. I investigate the potential contribution of multi-scalarity in analyzing energy poverty. This is achieved by using Buhera, Ward 24 as a case study and teasing out how it relates with other scales. The article offers a nuanced approach to energy poverty by interrogating multi-scalar relations of power, as opposed to stressing the "local." Reaching solutions in the face of energy poverty, decision makers require an appreciation of multi-scalar dynamics, and this unsettles the dominant binaries and master narratives that constrain the way in which energy poverty in Buhera is understood (Brown and Purcell 2005). Furthermore, with an understanding and appreciation of the multi-scalar approach, I pursue an "applied people's geography" (Harvey 1984; Howitt 1993). This requires an effort to understand and intervene in a particular issue with the aim of constructing concepts and abstractions that cast light on the relationships and processes that produce unjust, unsustainable and inequitable realities. This enhances social justice by influencing pro-poor policies in the energy sector: a multi-scalar approach penetrates social reality by tackling issues that are normally taken for granted.

The study presents strong evidence that scale relations are power-laden - failure to appreciate this results in the subordination of women in the energy sector. Previously studies on energy poverty tend to show a simple description of the phenomenon in various places rather than establishing how inequalities in electricity access occur. The focus has been on the time spent, and the drudgery suffered by women in gathering fuelwood for household cooking needs (Bryson and Howe 1993; Horestein 1989; Tinker 1987). By embracing a multi-scalar approach, this study attempts to transcend surface descriptions and to "analyze the specificity of mechanisms of power, to locate connections and extensions, to build little by little a strategic knowledge" (Foucault 1980: 145).

The remainder of the article is organized as follows: Section 2 analyses the theoretical framework that informs the study. Section 3 briefly discusses relevant literature in this context. Section 4 describes the methodology adopted and the case study area. Section 5 and its sub-sections present the findings and discussions. Finally, section 6 presents some conclusions drawn, and policy implications.

\section{Theoretical framing: multi-scalar analysis of energy poverty}

There are no common definitions for scale, even within disciplines and especially in the social sciences (Sayre 2005). In simple terms, scale refers to a "level of representation" (Johnston and Gregory 2000). However, since the early 1990s the study of scale has included social, economic and political perspectives. This shows that scale is susceptible to human manipulation. In that vein, political ecology's multi-scalar approach provides a significant theoretical framing for investigating the context in which inequalities in access to electricity in Buhera are perceived and experienced. A multi-scalar approach examines relationships between and across individuals, communities, the state, regions and international agencies (Blaikie and Brookfield 1987). Put differently, a multi-scalar approach follows a mode of explanation that evaluates the influence of variables acting at a number of scales, each nested within one another, with local decisions influenced by regional policies, which are in turn directed by global politics and economics (Robbins 2012). 
Informed by the multi-scalar approach, there are various issues that contribute to inequalities in access to electricity. Consequently, energy poverty cannot be regarded as a purely "local" phenomenon. Energy poverty should be understood in the context of a series of scales such as conditions of production of electricity, social organization of production, the national political economy (inequalities of class and region) and the international political economy. Thus, Howitt's (1998) famous musical metaphor of scale as a relation is pertinent, since energy poverty should not be seen as an independent phenomenon; rather it should be understood in a complex web of relationships, just like musical notes. It is in this relationship where any change in one note affects the whole scale, illustrating the interdependency of social factors. The concern does not lie in discrete measurements of energy poverty in terms of its magnitude per se, but rather in exploring relations among the phenomenon in question.

Marston (2000) and Smith (1992) contend that the products of economic, political and social activities and relationships are far from neutral and fixed geographical scales. In that light, any analysis is incomplete that fails to address scale based on the understanding of the social processes that are shaped and constituted at different levels in the electricity sector. Energy poverty as a relational phenomenon is under-researched in Zimbabwean energy scholarship. It is applying the social construction of scale that can provide more powerful insights into the nature and dynamics of complex "geographical totalities", and a stronger foundation for delivering an applied people's geography (Howitt 1998). Howitt (1998) states that geographical totalities are analyses of all encompassing factors such as geo-politics, territory, structure, culture, history, economy, environment and society. In the geographical totality, many elements will remain consistent in a geographical analysis that spans across different scales. As I will show, what changes in such analysis are not the 'actants' such as the electricity grids or production of electricity, but the perceived relationship between actors and the ways in which the electricity is distributed and consumed. For that reason, scale is not ontologically given (Marston 2000), and to insist on the essential existence or priority of any scale is scalar fetishism (Towers 2000).

Access, or lack of access to electricity is dependent on how power circulates through and mediates relationships at various scales. In other studies, Brockington and Duffy (2011) illustrate how the power of capitalism produces and reproduces itself through conservation. Similarly, this study links electricity issues with various scales to escape the "local trap" (Brown and Purcell 2005: 608). The local trap is an assumption that organization, policies and action at the local scale are inherently more likely to have desired effects than activities organized at other scales. Further informed by Brown and Purcell (2005), the local is not solely local and the global is not purely global. This line of reasoning suggests that energy poverty in Buhera, Ward 24 cannot be addressed without considering the social processes at other scales.

\section{Energy poverty in Zimbabwe: a political economy context}

By embracing a political-economic perspective, we position the rural as the product of broader social, economic and political processes (Wood 2009). It is important to look beyond a functional perspective that seeks to fix rural space through the identification of its distinctive fundamental characteristics. Brown and Purcell (2005) state that a functionalist perspective does not appreciate that scalar configuration is a strategy used by political actors to pursue a particular agenda. In his study, Kaseke (2011) describes the impact of power outage on different sectors in Zimbabwe. He suggests further that the main intervention could be the improvement in electricity supply through investment in generation capacity expansion at national level or at the regional power pool level. Kayo (2002) in her study on power sector reforms in Zimbabwe, recommends that privatization could actually turn the situation for the better at the expense of the national power utility the Zimbabwe Electricity Supply Authority (ZESA). While their arguments are plausible, these interventions would only succeed if they appreciate the complexities of national political relations and outcomes. The political agendas of all actors in the electricity sector must be understood - the political struggle across scales. Electricity production and access cannot be understood by reference only to the national territory. Borrowing from Swyngedouw (1997), the theoretical and political priority never resides at a geographical scale, but rather in the process through which particular scales become constructed. 
In this context, international influence in the Zimbabwean energy sector is instructive. China is now the single largest source of external finance for power generation investments in Sub-Saharan Africa (African Progress Panel 2015). The African Progress Panel states that estimates put Chinese official development finance to the region's energy sector in excess of US\$16 billion between 2000 and 2012, which is more than double the financing for Independent Power Producers (2015: 99). In Zimbabwe, during an official visit in November 2004, ZESA Holdings signed a co-operation agreement with a Chinese company (CATIC) for equipment worth a total of US\$2.4 billion (Friedrich-Ebert-Stiftung 2004: 6). The agreement was set to provide for the expansion of the power plant in Hwange with two new production units of $300 \mathrm{MW}$ each, so as to reduce Zimbabwe's dependency on electricity imports from Mozambique and South Africa (ibid). These partnerships have not been without controversy. Chief among the concerns is that the finance for infrastructure in Africa by China is motivated by a need to secure access to Africa's natural resources on terms favorable to China and by Chinese commercial interests (Mapaure 2014).

As far back as 1991, Zimbabwe received Official Development Assistance (ODA) from various countries including the United Kingdom, which contributed US\$53 million and Germany which contributed US\$51 million (Rowland 1994: 138). Rowland (1994) further explains that the most obvious way in which donors affect the supply of electricity is by either granting or withholding money for power projects. As such because of Zimbabwe's modest resources and the capital-intensive nature of the energy sector, the presence or absence of donor money has made a difference because ODA is tied or conditional. For instance, much of the aid given by Organization of Economic Cooperation Development (OECD) countries is 'tied', in that the beneficiary is expected to purchase project equipment from the aid-giving country (ibid). Many power stations in the developing world owe their existence not to any proven need, but to vigorous lobbying by donor country manufacturers and construction companies (Foley 1991). In this context, Taylor's (1982) appreciation of scale in political ecology is important, where its roots lie in the political economy of the global (the scale of reality), national (ideology) and local (experience scale). His observation suggests that the global scale really matters because conditions tied to funding in the electricity sector are a characteristic of capital accumulation.

Another example of interference from a broader scale is the conditionalities laid out by lending institutions such as the World Bank. Söderholm (1999) observes that during the 1990s the Bank was willing to finance cost-efficient energy options. Rowland's (1994) earlier observations concur with Söderholm's (1999) that the World Bank has had an influential role in the electricity policy debate in Zimbabwe for a long time, offering support and legitimacy to some alternatives while condemning others. For that reason, it appears that the factors that influence electricity access are too complex to be contained within the energy sector; some of them result from national or even international decisions.

Loans like the one extended to Hwange Coal Power Station by the World Bank between 1982 and 1992 had a direct, negative impact on citizens of Zimbabwe. What complicated the situation is that on completion, the power plant produced less electricity than expected - 37\% below the World Bank prediction in 1987, and 27\% below in 1990 (World Bank 1992, cited by Jones 2011: 15). The devaluation of the Zimbabwean dollar against the United States dollar had a significant impact on repayments. The major condition implemented by the World Bank was to increase electricity prices so that the Zimbabwean public electricity company would be able to use money from electricity consumers to pay $30 \%$ of their debt repayments. Electricity prices ended up 7\% higher for the general public (Jones 2011: 15). Cheryl Payer called this "the debt trap" - a process of hooking in even the poorest countries to the system of capital circulation so that they can be available as sinks for surplus capital for which they are judged to be liable (Harvey 2003: 118, my emphasis). As illustrated by the Hwange debt, it is the receiving country which has to compensate for any devaluation of capital, by charging its own citizens more while protecting the creditor country's currency from devaluation. In that scenario, a simple law of nature is confirmed - that those with money tend to accumulate more of it because they can set the terms on which it is lent, so the gap between the rich and the poor continues to widen. In his words Stiglitz queried, "What a peculiar world in which the poor countries are in effect subsidizing the richest" (Harvey 2005: 162).

While Mangwengwende (2002) implicitly referred to a multi-scalar approach by pointing out that it is important to analyze the consumption patterns and incomes of consumers in order to design a tariff structure, he did not present empirical evidence to show how the poor relate to the scales above. Section 5 addresses this 
gap by presenting the intricate complexity of scale (by securing views from rural people and the electricity providers). Through a multi-scalar analysis, it is noticeable that Zimbabwe's major indigenous options for power production are coal and hydro, but both have potential environmental costs. If environmental concerns continue to occupy an important position on the global agenda, then Zimbabwean electricity supply could be affected by international environmental policy and legislation (Rowland 1994). Rowland observed that given the combustion of coal which produces atmospheric damage, many donors made their loans for coal-fired power stations conditional upon a cleaner generating process. By insisting upon advanced technology to control further Sulphur emissions, coal will increase electricity prices by perhaps 10 to $20 \%$ and this makes electricity more expensive to the end user, especially the rural poor (1994: 140).

Environmental issues often entail a particular bias in terms of who defines and measures them (Harvey 2005). Hence, failure to appreciate this complexity will result in energy projects or infrastructure that does not serve the poor. In a similar vein, the appropriate technology movement ${ }^{2}$ has an interest in moving away from reliance upon non-renewable energy sources (fossil fuels in particular) towards increased conservation and use of renewable energy resources; while particular regard is put on the interdependency of the global South and the North (Flavin and Pollock 1985). Its major flaw is its inherent technological determinism (Willoughby 1990). Supporters are frequently inclined to the view that socio-political structures, like decentralized governance, are determined by technology, and that desired socio-political changes may be brought about by technological means (ibid). Conversely, following Chambers (2010), it is more likely that rural systems are complex, diverse, dynamic, uncontrollable and unpredictable. For this reason, redressing a lack of energy technology is only a partial response.

\section{The case study area and methodology}

This study draws on fieldwork carried out in Buhera (Ward 24) between September 2016 and January 2017. Buhera (Ward 24) falls under Buhera District, one of the seven districts in Manicaland Province (see Figure 1). Buhera was chosen because of its extensive reliance on fuelwood in the absence of other energy sources. Reddy et al. (2000) define energy poverty as the absence of sufficient choice in accessing affordable, reliable, high quality, safe and environmentally benign energy services to support economic and human development. In the district $93 \%$ of people use wood in the home, $3.2 \%$ use electricity, $0.1 \%$ use paraffin and 3.2\% rely on other sources (Zimbabwe National Statistics Agency 2012: 144). From this energy balance, one can infer that the area has high energy poverty.

A dialogic and dialectical qualitative research approach was employed. A case study allowed an indepth analysis, situated within a wider theoretical discussion. Convenience sampling was used to recruit 60 participants, and this included 20 women. Respondents were those who were readily available (Davies 2007). While I acknowledge this limitation, the study is qualitative in nature and the aim was to make the best out of the participants willing to participate. In addition, secondary information from previous studies, and governmental and NGO sources was collected. Fifteen key informants were purposefully sampled from the Ministry of Energy and Power Development (MEPD), Zimbabwe Electricity Supply Authority (ZESA) and the Rural Electrification Fund (REF). Semi-structured interviews were carried out and in some cases intentional conversations were held. The reason for adopting such a strategy was to facilitate less formal interaction. Ethical considerations prevailed at every stage of the study and confidentiality was maintained by use of pseudonyms. $^{3}$ Although the sample was limited, the evidence indicates that energy poverty cannot be understood solely at rural household level independent of the local community, the government, the nature of the state and the international relations.

\section{Data analysis}

Two approaches to data analysis were used. First, content analysis was carried out, in which the transcribed interviews were coded according to the different perceptions of energy poverty in a multi-scalar

\footnotetext{
${ }^{2}$ Small-scale and decentralized energy supply that is efficient, environmentally sound, and locally autonomous.

${ }^{3}$ Interviewee codes are used in the analysis below.
} 
context. Thereafter, critical discourse analysis made sense of the government actors' views on energy poverty. Critical discourse analysis gives focus to the non-discursive elements of a discourse (Bryman 2008). The primary concern was not to analyze the way language is used, but to investigate the extent to which discourses can be traced back to the interests of particular groups in providing and accessing electricity. Discourse analysis helped to establish the context of framing and power relations that permeate energy poverty. As a result, the results presented and discussed in the following sections show how energy poverty is perceived at various scales due to asymmetrical power relations.

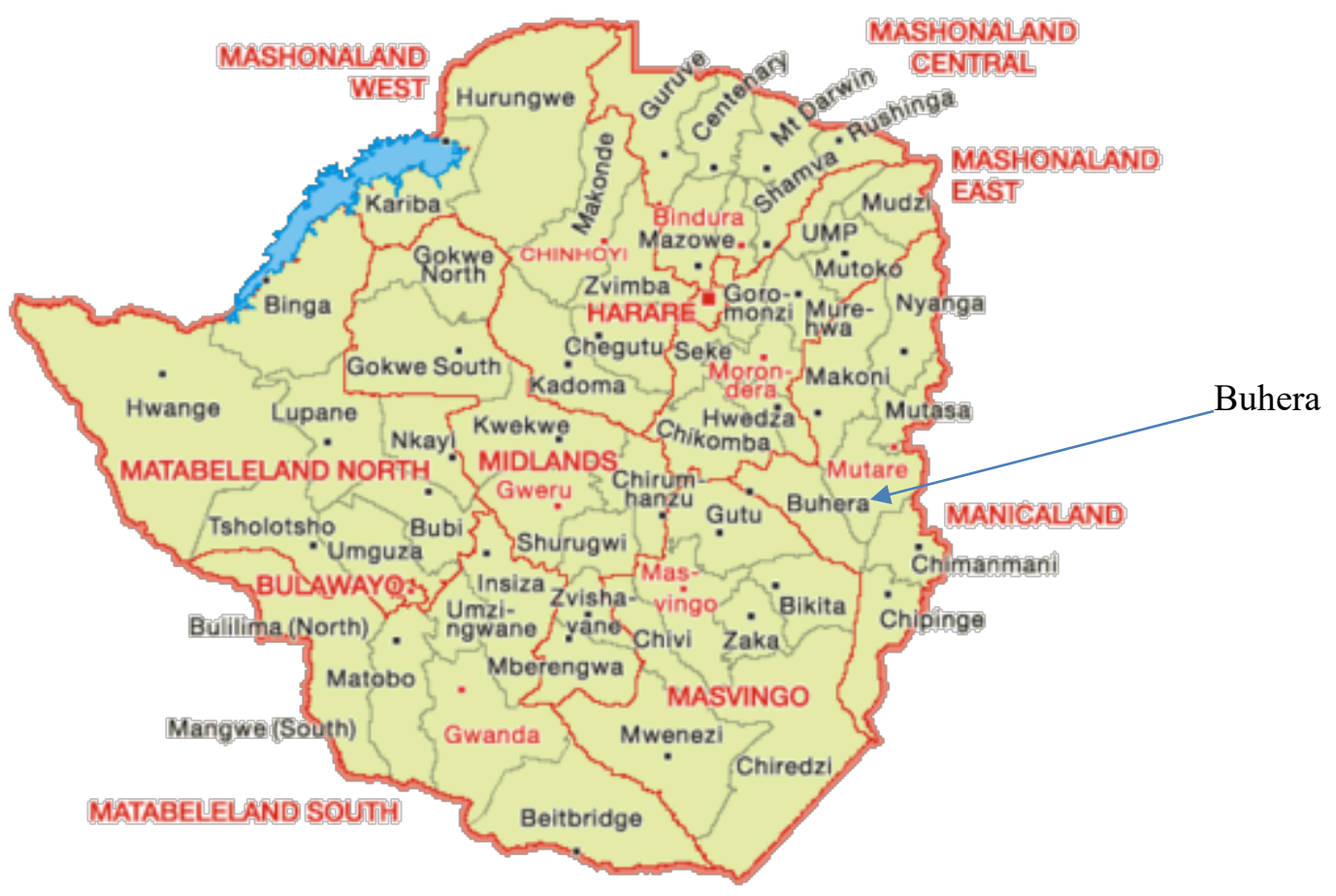

Figure 1: Map of Zimbabwe, showing research site. Source: FAO/WFP (2009)

\section{Findings and discussion}

The findings and discussion are structured based on the local and bureaucratic framings of energy poverty.

\section{Household scale patriarchy}

Interviews with local women indicated that they suffer the effects of energy poverty. The contextual data show that the home is a crucial terrain of political struggle. Contrary to the general view that rural electrification brings development and lessens the burden on women for their daily duties, it appears that electrification per se does not automatically equalize gender relations. Observations made at one electrified homestead revealed their access to electricity has not changed the duties of the woman of the household. BF2 explained: 
Yes, we have electricity; we managed to connect from the line which serves the school and the township, all thanks to our son who is working in South Africa. However, the electricity is providing us mainly with light, connection of the television, small fridge, garden water pump, charging of phones and it also allows us to feed our broilers during the night.

Curiously, after mentioning these benefits, this respondent did not mention anything about cooking. I wondered why. Probing further, she indicated the male household head believed that "we can continue using fuelwood for cooking because this is what we have always been doing." She said "what pains me is that duties such as fuelwood collection and cooking are not considered as important in the home. It is considered as an obligation."

The evidence suggests that not only are asymmetrical power relations evident in the home, but labor is undervalued. Furthermore, it is quite revealing that gender relations under the larger system of patriarchy result in inequitable distribution of resources in the household based on gender and sex (Marston 2000). In this instance, the patriarchal effect in the use of electrical gadgets in the home implicitly contributes to the social construction of scale. This finding contradicts Tinker who submitted that "the real rural energy crisis is women's time" (1987: 146). She observed that technologies such as improved stoves, that reduce drudgery suffered by women who must collect fuelwood, can solve the rural energy poverty problem. Empirical evidence from Buhera, Ward 24 shows otherwise: technological intervention alone is not adequate without addressing structural inequalities such as unequal gender relations and patriarchy. To substantiate this argument, BF19 explained:

As women, we tend to lose interest in electricity issues because mostly men are the ones who have gadgets which need electricity such as televisions and radios. Even if we buy them jointly, they are the ones in control.

While in Zimbabwe, many studies have been done on women and agriculture such as Gaidzanwa's (2011) work on women and land in Zimbabwe and Jirira and Halimana's (2008) gender audit of women and land rights in Zimbabwe. But there is a dearth of empirical research on women and electricity supply. This permits the pervasive belief that rural electrification can emancipate women from unequal gender relations. Thanks to the empirical evidence from Buhera, for rural electrification to be meaningful to both genders, there is need to work on power relations in the analysis of women's and men's roles in electricity management. Other scholars such as Annecke (1999) have made similar observations in South Africa. I add that this appreciation can only be achieved through the understanding of a variety of key phenomena at multiple scales: social actors and practices, political processes, and environmental factors.

To turn around the status quo, the starting point depends in part on women's preparedness to take up the struggle. However, it is apparent to recognize that culture is strongly entrenched among local women; hence change is difficult or unlikely to occur. When asked how they feel about their energy poverty status, almost all female participants responded that, musha mukadzi (this means that no matter what difficulties a woman faces in the household, she must remain strong as the strong pillar of the home). This shows true subjection to their culture without any negotiation for their space and sense of self in the home. This observation supports $\mathrm{O}^{\prime}$ Keefe et al.'s finding in Kenya where they discovered the impact of cultural influences on woody biomass production and utilization (1989). They state that women neither plant trees nor take fuelwood from the farm trees, which are allocated to other farm uses. The similarity of these findings shows that the discourse about energy poverty at local level is constituted incorrectly, where it is perceived as inevitable, but without appreciating cultural and patriarchal powers. The complexity of women's position is evident in the interplay between place, power and culture.

Furthermore, it emerged that women are more involved in beer brewing than men. This is an energy intensive activity which needs wet wood as a source of fuel, and as such they are labeled as chief contributors to deforestation. However, BF15 retorted: 
The situation is forcing us. Beer brewing used to be an occasional activity, but because of the situation in the country beer brewing is now our bank [sic]. This is because since our husbands and children are no longer sending money as they used to due to cash crisis, we have to make a living on our own.

Her explanation links an ecological perspective with analysis of economic and political power and with policies and actions taken in a local context (Rocheleau et al 1996). Site-specific issues such as deforestation caused by cutting wet wood for fuel are a result of the struggling national economy. BF7 explained better:

Our government has always stopped anything that enabled us rural women to gain an effective degree of autonomy. We do not have the capabilities. I believe they do it intentionally such that the state manipulates us.

These sentiments support Nussbaum's (2000) observation that women lack essential support for leading lives that are fully human. The danger is that without understanding of why women are venturing into such socalled ecologically destructive activities, policy measures will restrain women in their activities like beer brewing, hence limiting their livelihoods. Following Smith (1992), a household is a socially produced scale. It embodies social institutions and processes such as social reproduction and gender relations, particularly patriarchal domination in the household.

Asked what challenges women are facing in the energy sector or at household level, an NGO practitioner working on women and energy said:

What I noticed is that women can participate well on energy issues when they are alone, but when there are some visitors such as NGO practitioners, they are really shy. This makes them vulnerable to some interference. Although women are active in participation at the grassroots, when we invite them for higher level fora for example in Mutare or Harare they are not allowed by their husbands. For that reason, there are few women in management committees.

This quotation is replete with meaning. It suggests how patriarchy plays its role in disadvantaging women in the energy sector. Power "over" is being exercised by their husbands such that women do not participate in high level energy platforms. Due to patriarchal constraints, the question of who is included as participants can be recast as a question of socially constructed scale (Smith 1992). Describing the drudgery suffered by women does not allow thinking more broadly about what should be done to turn around the status quo.

In a bid to capture the government's perspective on women and energy, I asked what the Ministry of Women's Affairs, Gender and Community Development is doing to help women cope with energy poverty. A senior community development officer said:

We are busy at work as a Ministry; for instance, we are encouraging rural women to participate in projects such as distributing liquefied petroleum gas (LPG). In conjunction with the NGOs, the gas is sold to women at a subsidized rate and then they would resale for a profit. That way, we are sure that they are getting some income. (Senior community development officer)

The officer's response indicates that the Ministry is more concerned about the productive role of women in the energy sector than their strategic positioning. This strategy by the Ministry emanates from the Women in Development (WID) approach which is popularized by the United States Agency for International Development (USAID). The underlying rationale for WID is that women are an untapped resource that can provide an economic contribution to development; hence it promotes income-generating projects for women (Moser 1989). It is generally accepted that WID projects would improve women's efficiency, which would in turn contribute to economic development. Although the WID approach might be helpful to a point, it does not 
address the women's positions in the energy sector. The attention given to productive and practical needs (as a response to immediate perceived necessity) does not challenge conventional social relations in order to address strategic gender interests in the energy sector. Strategic interests mean women gaining more equality with men and transforming gender relations (Molyneux 1985). Put simply, the success of strategic needs lies in implicit redistribution of power. In that context, the Ministry's commitment to productive, practical needs over strategic ones suggests that energy poverty is not a natural phenomenon to women. Rather it is shaped by the contingent social relations where women are subordinated to men in Zimbabwean patriarchal society. This claim can be substantiated further by a key informant from one NGO, who said:

In the energy sector, the males dominate. We have that female chief executive officer at Zimbabwe Energy Regulatory Authority and another woman who is the current chairperson of the Zimbabwe Energy Regulatory Authority board. With the exception of those two, who else? None. There is still a lot of work to do concerning women inclusion in the energy sector.

In this context, the increased participation of women in the energy sector can help to incorporate gender as an integral part of energy policies and practices. Although their participation is a step in the right direction, women's inclusion does not guarantee the adoption of gender sensitive policies. This is because gender relations are embedded within the ministerial administrative system. For that reason, feminist gender planning is needed, as compared to mere feminine representation in the electricity sector.

\section{Rural communities: victims of the broader scale}

Empirical evidence shows that households are not closed entities; but rather are relational entities affected by decisions taken at a broader scale. Asked about the reason why they do not have electricity in Buhera (Ward 24), participants stated that they are very poor, and they do not have money. One male participant (BM7) said:

Poverty, poverty is upon us. However, it is not necessarily out of our own making, but the situation in the country. We used to grow crops and sell our products to the Grain Marketing Board, the depot used to be at Buhera Office, but it's gone. As such we now entirely rely on selling our products to those from town. It is not us who set the prices, rather they tell us the price they prefer us to sell our products at. Also, there is no money in towns; we are told by our children in Harare that they spend many days waiting for cash from banks. So, poverty is the main reason why most people cannot have electricity.

Due to poverty and unsustainable livelihoods, rural people are unable to connect to electricity. As noted, deforestation is an outcome of the search for fuelwood. BFI concurs with BM7 and explains further:

Poverty has gotten into our woodlands. We no longer fetch wood to use in the kitchen only, but for burning bricks for sale where 1000 well-made bricks can give me US\$30 and for brewing beer, I need about three scortch-carts of wet wood or selling the fuelwood in the township for survival especially the jobless youths (Tiri kukiya-kiya because of the situation).

Kukiya-kiya is known as a new logic of economic action in post-2000 Zimbabwe, practiced largely in in urban areas. But this respondent refers to his rural setting and specifically to energy poverty. Kukiya-kiya means the multiple forms of 'making do', an instinctive response to circumstances (Jones 2010). People resort to strenuous or difficult activity with an eye to fulfilling basic needs in the hardened face of reality. Several participants referred to the "situation in the country." I infer that by "situation in the country" they are implying that the broader national economy which includes a cash crisis at banks, the fall of parastatals, and a chronic lack of employment affect them. It plays a role in using their woodlands in a degrading manner. Blaikie and 
Brookfield's (1987: 27) "chain of explanation" argues for such an analysis. The "chain" refers to cross-scale (multi-scalar relations) of a community, its landscape and ecological system. The degraded environment and landscape, which even though it initially resembled the outcomes of communities' abuse of the environment, is an outcome of the complex processes of social relations between the local people and the electricity service providers. Therefore, the chain of explanation shows how identities and institutions at different scales have affected the local: Buhera (Ward 24).

In an energy poverty scenario kukiya-kiya can be paralleled with "desperate ecocide" (Blaikie 1985: 138). In Blaikie's view, there is a reciprocal link between poverty and environmental forces where a poor peasantry causes environmental degradation because of their poverty and desperation. In turn, environmental degradation exacerbates their condition. For instance, they cut live timber to use for cooking because they do not have an alternative and also, they need income for their survival which in turn forces them to cut wood for sale. These practices can contribute to deforestation which then affects them negatively. Therefore, scale must be understood in its entirety - its 'geographical totality.' This suggests a lack of access to electricity, and local deforestation, is not caused by local factors alone. Rather, place-based and higher order factors should be viewed in concert.

BF9 illustrates this in her response to the reason why their poverty has recently soared. She explained:

It is the situation in this country, there is no other better explanation than that. We used to have bumper harvests such that we could have enough for consumption and sell the surplus, but for the past 5years or even more, we have been experiencing increased incidences of drought due to unreliable and unpredictable rainfall patterns. This is new to us, this has not been the case before and that is exacerbating our poverty because we are now only focusing on what to eat and not other basics such as electricity.

These sentiments show how changes in the climate have impacted livelihoods through increased incidences of drought. Such a threat to sources of income in her community implies that they cannot afford expenses such as electricity connection and monthly payment rates. BF9 corroborates:

Under such circumstances whereby our livelihoods are not stable, we can't think of budgeting for electricity rather we budget for food and school fees. Those are the priorities because the situation in the country is not permitting.

In this section, empirical evidence has fulfilled Eric Wolf's call for the need to examine political factors outside the community and "over which the community has little control" when discussing a specific case of unequal social relations (1972: 203).

\section{Government perspectives}

From the viewpoint of government and policy makers (including all actors participating in policy design), the study shows that neither the underlying causes of energy poverty nor its impact are transparent. Rather, there are hidden mechanisms which need to be revealed through critical discourse analysis. This is synonymous with the "peeling of an onion" as each layer of underlying reality is revealed (Forsyth 2003: 220). Drawing from interviews with the state bureaucrats involved in electricity service delivery, it became clear that their framing of energy poverty is different from those of the local people. Asked what dictates their service delivery duties, an MEPD official said:

It is very difficult for some of these things. Of-course we want our people to be empowered by all means possible, but sometimes we have to bend the rules for economic development especially in the lucrative mining sector. 
It is revealing that the state advocates for macro-economic growth policies at a national scale, which in turn affect local people individually. The policy elites believe that economic growth will result in development for all, trickling down to allow access to electricity for all. However, history shows that citizens often wait for a trickle-down effect that never materializes (Harvey 2000). The sentiments by the MEPD official concurs with the Zimbabwean energy policy of 2012 which states that:

The generation and retail supply are competitive businesses, while transmission and distribution are natural monopolies. Because of the small size of the industry in Zimbabwe, generation and retail competition is for the market rather than within the market. (MEPD 2012: 8)

Analysis of this energy policy shows that rural people are victims of the policies decided elsewhere and by bureaucrats who do not experience the effects of energy poverty. Drawing from Foucault (1979: 20), the very existence of a field of concern termed "policy" should itself be treated as something to be explained. Accordingly, Zimbabwean energy policy cannot be viewed as natural, but rather as a political "technology." Political technology pays attention to the actual mechanisms through which authorities of various sorts have sought to shape, normalize and instrumentalize the decisions and aspirations of others in order to achieve the objectives they consider desirable (Miller and Rose 1990). In this context, the language of market-based service provision shows the political rationalities and regulatory aspirations of the government. Its neoliberalism is revealed in its actions - promoting sectors such as mining at the expense of the rural people. Neoliberalism serves the aspirations of the state, and keeping control of electricity supply is part of this agenda. It fails to cater for rural peoples' needs because of an indifference toward the socially weak. Sadly, neoliberalism is perceived as a solution that can make the electricity sector more efficient, when in actual fact it is the contributing factor to energy poverty because it has the purpose of serving the market. The social construction of scale involves strategic manipulation by powerful groups (government actors/electricity providers) to justify their actions.

The MEPD's influence on access to electricity is dirigiste. The state plays a strong directive role, as opposed to merely a regulatory one (Suding 1989). Electricity is channeled to selected sectors for profit maximization, as articulated by the MEPD official. Dirigisme is visible across Zimbabwean energy policy, which promotes the efficiency of the market, and argues that generation and retail competition for electricity supply is for the market (MEPD 2012).

Systems of knowledge and beliefs were evident in interviews with government actors. Discourse not only expresses meaning about social phenomena, but actively produces knowledge as objective truth (Robbins 2012). Consequently, textual analysis was helpful in showing how government actors produce and sustain certain "truths" which affect the lives and livelihoods of the rural people. In an endeavor to sustain the economic growth agenda, ZESA Holdings instituted a system of billing whereby the more electricity the consumer uses, the more one pays (Bulawayo News24 2013). This is done in the name of inculcating a culture of saving electricity. A tokenistic fee of 50kWh of electricity billed at 2 cents per unit is given to all consumers connected to electricity, but there is a sharp increase in the second consumption tariff (between $51 \mathrm{kWh}$ and $300 \mathrm{kWh}$, charged at 11 cents per unit). Many rural people cannot afford this higher-priced electricity. Bond et al.'s (2011) study on uneven and combined Marxism in South Africa is insightful here. Due to failure to access electricity, rural people turn to fuelwood as their alternative. This is not an easy option because more often, they are labeled as chief contributors to deforestation as advanced by the crisis narrative - "the other energy crisis" (Eckholm 1975). It is clear that the neoliberal approach does not take into account rural people's predicament because the system produces energy consumption rationales that are in line with the economic values of the market.

In addition, analysis of the billing system showed that energy policy can be used to influence energy consumption in various ways. This is achieved by confining consumer choices. The billing system is embedded in the task of allocating resources. However, this is done in an indirect way in which the elements of social exclusion cannot be easily recognized. Analysis of the empirical evidence suggests that by confining the consumers' choices, the power utility seeks to maintain the supply-side. However, this approach is flawed in that the electricity service providers neither construct more electricity infrastructure nor increase electricity 
generation to add into the national grid. Rather they reduce rates of growth of consumption to improve security of supply.

This is reinforced by an official at the Zimbabwe Electricity Transmission and Distribution Company (ZETDC):

What dictates us is meeting the needs of our customers because we are in business, in the rural areas connection fee is currently at US\$95 and it can actually be more depending on the terrain.

The bureaucratic attitude towards electricity access diverts attention away from the unclear policies and internal incoherence existing to serve the interests of the state. The technocrats do not negotiate with the local people whose lives and livelihoods are affected by their decisions. ZESA Holdings was unbundled in 2013, an outcome of power sector reform. ZESA developed into separate generation, transmission and distribution companies. Commercial principles require the utility to earn a market-related return on equity ((Karekezi and Kimani 2000; Karekezi and Mutiso 1999). In this regard, the lack of access to electricity by rural people because of high connection fees (US\$95) might be a result of this neoliberal restructuring and its financial targets. This is because the unbundled entities of ZESA now operate on a market competitive system; hence the connection fee becomes unaffordable to the rural majority.

Asked about his view of what could have caused electricity shortage in the country, a top government official in the MEPD said:

It is neither the general citizenry's fault nor can we try to find a scapegoat such as overpopulation. The issue is that since independence the government did not invest in electricity generation sources. What happens when planning for electricity is this: you consider everything, you project your demand and you look at prospects of economic growth, population growth and you look at it holistically and you come up with a projected demand and plan how you are going to meet the demand such that you know at such a time, a plant of a certain capacity should be commissioned.

The overpopulation thesis in the quotation above was unpopular with rural people, since it vindicates the government of any wrongdoing (in this case it did not make investment in the energy sector when it was viable). It may explain some shortages of electricity, but this is blaming the victim. Energy poverty can be attributed more to national planners than to the rural people. Circumstances beyond the rural peasants' control impact on them negatively.

In the same vein, some national level policies impact on local people who were not part of their planning. A ZESA executive said:

Some national policies particularly the Indigenization Policy are not doing any good to the capital-intensive energy sector. I know of independent power producers from outside who wanted to invest in the energy sector such that at least we could have enough electricity in the country, right now we have a demand of 2,200MW, but our capacity is only 1,100MW. It is such controversial policies which chase away investors. As such it is not necessarily about the policies in the energy sector per se, but the national policies and processes are quite inimical to investment in the electricity sector.

This evidence shows that electricity access is relational and complex. In addition, it shows that politicaleconomic processes condition a lack of access to electricity. But political governance issues are rarely debated in Zimbabwe, given its recent political history. Hence energy poverty is considered as an apolitical phenomenon, even though interviews suggested the imbalance in electricity access is created intentionally by those in positions of power. A Rural Electrification Agency executive lamented how they are derailed from their projects by politicians. He explained: 
In most cases our projects are hijacked by Members of Parliament (MPs) and as a result we end up electrifying some areas which would not be on our roll out.

Tellingly, social power positions vary considerably. In this context, Massey's observation is applicable when she questions in what sense are "regional" problems "regional?" (1994: 63). This question can be usefully applied to this study, rephrased as "in what sense is rural energy poverty rural?" It is evident that relational political processes as shown in the REF executive's view can socially produce scale. This reinforces the idea that scale is made and not given, that scale is not a pre-ordained hierarchical nomenclature for ordering the world, but rather a contingent outcome of the tensions between structural forces and the interventions of human agents (Marston 2004). Taylor lends support to my argument that there are "no natural" scales (Taylor 2004). The assignment of activities - for instance, proposed constituencies to be electrified by MPs - is contingent upon those with power who influence outcomes amenable to their ends. Ultimately, the production of any scale is political.

Asked whether renewable energy is a solution to energy poverty in the rural areas, there were contradicting responses between the policy elites and the rural people. A senior energy advisor from an International NGO on energy and environment said:

We are heading in the right direction especially given that we have partnered with the government in crafting the renewable energy policy for Zimbabwe. Furthermore, generally we have done well especially in terms of popularizing the use of solar energy in the rural areas. For us cooking is something else, we consider lighting to be the basic need and we are working hard in encouraging the use of solar energy.

Conversely, in Buhera (Ward 24), the majority of the participants showed negative attitudes towards renewable energy. Asked about how solar energy is helping them in the face of energy poverty, BF13 said:

Solar energy is not electricity. It is there just to give us light, charging our cell phones and sometimes playing the radio, otherwise it does not have much impact because our worry is on cooking. Solar energy does not cook, and I can't say I have electricity at my home.

\section{BM15 explained:}

Look, I have both solar panel and a battery, but the battery does not last long. So, with solar energy, I cannot confidently say I have electricity. Rather we need the actual electricity from the grid.

The evidence suggests that more often than not, so called "appropriate technologies" for the poor are likely to fail due to lack of appreciation of their use and the outright negative attitudes, as expressed in Buhera. It is clear that renewable energy is given much credit at the national scale without considering local outcomes, where the intended beneficiaries need solutions for the burden of food preparation using fuelwood.

\section{Conclusions and policy implications}

This study has demonstrated the importance of understanding the multi-scalar analysis of inequalities which cause lack of access to electricity in Buhera, Ward 24 in Zimbabwe. The Ward is embedded in wider social, political and economic forces and these explain how a lack of access to electricity is produced and reproduced in rural Zimbabwe. Energy poverty leads to a dissatisfaction with the national social and political order. It cannot be understood as an independent phenomenon; rather the individual household, the village/local 
community, the bureaucracy, the government, the state and international relations all affect electricity access. The conclusion is that energy poverty is socially produced. In addition, the household is a socially produced entity at the local scale, and patriarchal processes mean access to electricity does not automatically equate to equal benefit for men and women.

That being the case, the way forward lies with energy policy planners to question the social order and power relations, recognizing them as the origins of injustice in the electricity sector. Currently, that process is hindered by the prevailing discourse that sees energy poverty as a discrete phenomenon. Better policy outcomes would require the understanding of the differing and power-laden epistemologies between government actors and the local people. At least, this would bring harmony on how energy poverty is framed in the first place. Social injustice in the electricity sector comes in various forms and privileging government actors' views at the expense of the local perceptions misses the connections between them. The development of legislation should be done in line with questioning the relations between these actors and how these multiple levels interact. Accordingly, the multi-scalar inequalities in access to electricity might be addressed.

\section{References}

Africa Progress Panel. 2015. Power, people, planet: seizing Africa's energy and climate opportunity. Washington DC: Africa Progress Panel.

Annecke, W. 1999. From the kitchen to the boardroom: reflections on power relations in gender and energy practice and policy. University of Cape Town: Energy and Development Research Centre.

Blaikie, P.M. 1985. The political economy of soil erosion in developing countries. New York: Longman.

Blaikie, P.M. and H.C. Brookfield. 1987. Land degradation and society. London: Methuen.

Bond, P., A, Desai, T. Ngwane. 2011. Uneven and combined Marxism within South Africa's urban social movements: transcending precarity in community, labor and environmental struggles. Paper presented at Beyond precarious labor: rethinking socialist strategies. City University of New York Graduate Center (13 May 2011).

Brockington, D. and R. Duffy. 2011. Capitalism and conservation: the production and reproduction of biodiversity conservation. Antipode 42(3): 469-484.

Brown, J.C. and M. Purcell. 2005. There's nothing inherent about scale: political ecology, the local trap and the politics of development in the Brazilian Amazon. Geoforum 36(1): 607-624.

Bryman, A. 2008. Social research methods ( $3^{\text {rd }}$ edition). Oxford: Oxford University Press.

Bryson D.F. and M. Howe. 1993. Rural household transport in Africa: reducing the burden of women. World Development 21(11-12): 175-192.

Bulawayo News24. 2013. Residents angered by ZESA pre-paid meter billing system, Zimbabwe, Bulawayo (1 March 2013).

Chambers, R. 2010. Paradigms, poverty, adaptive pluralism. IDS Working Paper 344. Brighton: IDS.

Davies, M.B. 2007. Doing a successful research project: using qualitative or quantitative methods. Basingstoke: Palgrave Macmillan.

Eckholm, E. 1975. The other energy crisis: firewood. Worldwatch Paper 1. Washington: DC: Worldwatch Institute.

FAO/WFP. 2009. FAO/WFP Crop and food security assessment mission to Zimbabwe. Special report. Rome: Food and Agriculture Organization of the United Nations.

Flavin, C and C. Pollock. 1985. Harnessing renewable energy. In Brown, L.R (ed.) State of the world. New York: W.W Norton. Pp. 172-199.

Foley, G. 1991. Energy assistance revisited environment and development series. Paper No. 11. Stockholm, Stockholm Environment Institute.

Forsyth, T.J. 2003. Critical political ecology: the politics of environmental science. London: Routledge.

Foucault, M. 1979. Discipline and punish: the birth of the prison. New York: Vintage. 
Foucault, M. 1980. Power/knowledge: selected interviews and other writing 1972-1977. Brighton: Harvester Press.

Gaidzanwa, R.B. 2011. Women and land in Zimbabwe. Paper presented at the conference, Why women matter in agriculture. Sweden.

Gezon, L. 2005. Global visions, local landscapes: a political ecology of conservation, conflict and control in Northern Madagascar. Lanham, MD: Atamira Press.

Harvey, D. 1973. Social justice and the city. Oxford: Blackwell.

Harvey, D. 1984. On the history and present condition of geography: an historical materialist manifesto. Professional Geographer 36(1): 1-11.

Harvey, D. 2000. Spaces of hope, Edinburgh, Edinburgh University Press.

Harvey, D. 2003. The new imperialism. Oxford: Oxford University Press.

Harvey, D. 2005. A brief history of neoliberalism. Oxford: Oxford University Press.

Horestein, N, H. 1989. Women and food security in Kenya. Working Paper-Women in development. Washington DC: Population and Human Resources Development, the World Bank.

Howitt, R. 1993. Social impact assessment as "applied people's geography". Australian Geographic Studies 31: $127-140$.

Howitt, R. 1998. Scale as relation: musical metaphors of geographical scale. Area 30(1): 49-58.

Jirira, K. M and M.C. Halimana. 2008. A gender audit of women and land rights in Zimbabwe. Harare: Paper presented for the Zimbabwean Women's Resource Center Network.

Johnston, R.J. and D. Gregory (eds.). 2000. The dictionary of human geography. Oxford: Blackwell.

Jones, T. 2011. Uncovering Zimbabwe's debt: the case for a democratic solution to the unjust debt burden. London: Jubilee Debt Campaign.

Karekezi, S and J. Kimani. 2000. Status of power sector reform in Africa: impact on the poor. Energy Policy 30(11-12): 923-945.

Karekezi, S. and D. Mutiso. 1999. Information and statistics on the power sector reform process in sub-Saharan Africa. In Bhagavan, M. (ed.) Reforming the power sector in Africa. London: Zed Books. Pp. 331-352.

Kaseke, N. 2011. An estimate of the cost of electricity outages in Zimbabwe. PhD thesis. Nelson Mandela Metropolitan University: Department of Economics and Economic History.

Kayo, D. 2002. Power sector reforms in Zimbabwe: will reform increase electrification and strengthen local participation? Energy Policy 30: 959-965.

Mangwengwende, S.E. 2002. Tariffs and subsidies in Zimbabwe's reforming electricity industry: steering a utility through turbulent times. Energy Policy 30(11-12): 947-958.

Mapaure, C. 2014. Chinese investments in Zimbabwe and Namibia: a comparative legal analysis. Stellenbosch University, Center for Chinese Studies.

Marston, S.A. 2000. The social construction of scale. Progress in Human Geography 24(2): 219-242.

Marston, S.A. 2004. A long way from home: domesticating the social production of scale. In Sheppard, E. and R.B. McMaster (eds.) Scale and geographic inquiry: nature, society and method. Oxford: Blackwell.

Massey, D. 1994 [1979]. A global sense of place. In Massey, D. Space, place, and gender. Minneapolis: University of Minnesota Press. Pp. 50-60

Mehretu, A. and C. Mutambirwa. 1992. Time and energy costs of distance in rural life space of Zimbabwe: case study in the Chiduku Communal Area. Social Science and Medicine 34(1): 17-24.

Miller, P. and N. Rose. 1990. Governing economic life. Economy and Society 19(1): 1-31.

Molyneux, M. 1985. Mobilization without emancipation? Women's interests, state, and revolution in Nicaragua. Feminists Studies 11(2): 227-254.

Moser, C.O.N. 1989. Gender planning in the $3^{\text {rd }}$ world: meeting practical and strategic gender needs. World Development 17(11): 1799-1825. 
O'Keefe, P, J. Soussan, B. Munslow and D. Spence. 1989. Wood energy in eastern and southern Africa. Annual Review of Energy 14: 445-468.

Robbins, P. 2012. Political ecology: a critical introduction ( $2^{\text {nd }}$ edition). Chichester: Wiley-Blackwell.

Rocheleau, D., B. Thomas-Slayter and E. Wangari (eds.). 1996. Feminist political ecology: global issues and local experiences. London: Routledge.

Rowland, I.H. 1994. International influences on electricity supply in Zimbabwe. Energy Policy 22(2): 131143.

Sayre, N.F. 2005. Ecological and geographical scale: parallels and potential for integration. Progress in Human Geography 29(3): 276-290.

Smith, N. 1992. Geography, difference and the politics of scale. In Doherty, J., E. Graham and M. Malek (eds.). Postmodernism and the social sciences. New York: St. Martin's Press. Pp. 57-79.

Söderholm, P. 1999. The political economy of power generation in Zimbabwe since 1980. Natural Resources Forum 23: 335-346.

Suding, P.H. 1989. Policies affecting energy consumption in the Federal Republic of Germany. Annual Review of Energy 14: 205-239.

Swyngedouw, E. 1997. Excluding the other: the production of scale and scaled politics in Lee, R. and J. Wills. (eds.) Geographies of economies. London: Arnold. Pp. 167-176.

Taylor, P.J. 1982. A materialist framework for political geography. Transactions of the Institute of British Geographers. 7(1): 15-34.

Taylor, P.J. 2004. Is there a Europe of cities? World cities and limitations of geographical scale analyses. In Sheppard, E. and R.B. McMaster (eds.). Scale and geographic inquiry: nature, society and method. Oxford: Blackwell. Pp. 213-235.

Tinker, I. 1987. The real rural energy crisis: women's time. Energy Journal 87(8): 125-146.

Towers, G. 2000. Applying the political geography of scale: grassroots strategies and environmental justice. Professional Geographer 52(1): 23-36.

Willoughby, K.W. 1990. Technology choice: a critique of the appropriate technology movement. Boulder: Westview Press.

Wolf, E. 1972. Ownership and political ecology. Anthropological Quarterly 45(3): 201-205.

Wood, M. 2009. Rural geography: blurring boundaries and making connections. Progress in Human Geography 33(6): 849-858.

Zimmerer, K.S. and T.J. Bassett. 2003. Future directions in political ecology: nature-society fusions and scales of interaction. In Zimmerer, K.S and T.J Bassett (eds.) Political ecology: an integrative approach to geography and environment-development studies. New York: Guilford Press. Pp. 275-296. 